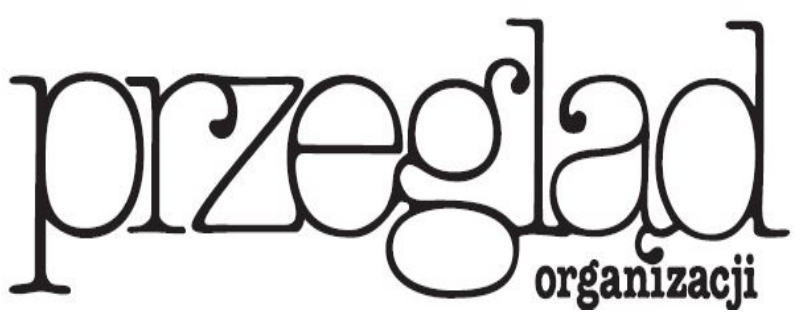

Miesięcznik TNOiK

Założył Karol Adamiecki w 1926 r.

\title{
DETERMINANTY JAKOŚCI FUNKCJONOWANIA FIRM SZKOLENIOWYCH
}

https://doi.org/10.33141/po.2018.09.04

Piotr Rogala

\section{Wprowadzenie}

W spółczesne organizacje funkcjonują w rzeczywistości, w której ilość wiedzy i informacji narasta lawinowo (Zimniewicz, 2003, s. 106). W tej sytuacji niezmiernie ważne stają się procesy ciągłego rozwoju pracowników będące nieodzownym warunkiem rozwoju organizacyjnego (Suchodolski, 2010, s. 231). Dostępne w literaturze przedmiotu wyniki badań wykazują, że odpowiednie rozwiązania dotyczące szkolenia pracowników przekładają się na wyniki osiągane przez organizacje (Baraki, van Kemenade, 2013, s. 492-506; Guerrazzi, 2016, s. 38-57). Wyzwaniem dla menedżerów jest więc zapewnienie dostępu do odpowiednich szkoleń, które podniosą poziom wiedzy i umiejętności oraz zwiększą sprawność działania, a także walory indywidualne pracowników (Gableta, 2005, s. 216). W tym kontekście szczególnego znaczenia nabiera jakość usług świadczonych na rynku szkoleniowym, a w szerszym ujęciu jakość funkcjonowania firm szkoleniowych. W przypadku Polski wskazać można wiele słabych punktów związanych z tym obszarem. Przede wszystkim rynek szkoleniowy jest rozdrobniony, działa na nim wiele podmiotów (około 60 tys.), często o niewielkim potencjale merytorycznym. Firmom takim trudno jest zapewnić wysoką jakość świadczonych usług, bowiem w wielu przypadkach ważne są przede wszystkim niskie koszty prowadzenia działalności (PKO Bank Polski, 2016). Napływające środki unijne doprowadziły dodatkowo do pojawienia się wielu negatywnych tendencji zarówno po stronie podaży, jak i popytu. Dotyczą one m.in. oczeki-
Przegląd Organizacji, Nr 9 (944), 2018, ss. 28-33

www.przegladorganizacji.pl @Towarzystwo Naukowe Organizacji i Kierownictwa (TNOiK) wania, że szkolenia będą darmowe lub bardzo tanie (Wawer, 2012, s. 448). Oferta firm szkoleniowych działających w Polsce koncentruje się głównie na zarządzaniu i kompetencjach miękkich, a jej dominującą formą są szkolenia zamknięte (Mika, 2010, s. 129).

Dostępna jest dość obszerna literatura dotycząca szkoleń. Warto zauważyć, że jest ona jednak uboższa niż w przypadku wielu innych rodzajów usług, np. świadczonych przez hotele lub banki (Nasseef, 2014, s. 148). Ponadto poruszane w niej tematy koncentrują się wokół kilku wybranych zagadnień, m.in. sposobów i technik przeprowadzania skutecznych szkoleń (Davies, 2007; Lee, 2012, s. 2597-2613), ignorując inne, np. dotyczące zarządzania firmą szkoleniową.

Celem artykułu jest identyfikacja oraz ocena znaczenia czynników, które mają wpływ na jakość funkcjonowania firm szkoleniowych. Zgodnie $\mathrm{z}$ definicją sformułowaną przez Międzynarodową Organizację Normalizacyjną (ISO), pod pojęciem jakości obiektu rozumie się „stopień, w jakim zbiór inherentnych właściwości obiektu spełnia wymagania" (PN-EN ISO 9000:2015, s. 23). Na tej podstawie można przyjąć, że jakość funkcjonowania organizacji to stopień, w jakim ta organizacja jest w stanie skutecznie realizować własne cele w dłuższym czasie.

Rozważania zostaną oparte na analizie treści wybranych standardów zarządzania firmami szkoleniowymi oraz wynikach badania ankietowego, którym objęto menedżerów firm szkoleniowych funkcjonujących w Polsce. 


\section{Standardy zarządzania firmami szkoleniowymi}

$\mathbf{S}$ ukces, jakim okazało się opublikowanie normy ISO 9001, zawierającej uniwersalne kryteria tworzenia systemu zarządzania jakością, zachęcił Międzynarodową Organizację Normalizacyjną do obejmowania normalizacją kolejnych zagadnień związanych z zarządzaniem. Opracowane i udostępnione zostały normy dotyczące m.in.: zarządzania środowiskowego, zarządzania aktywa$\mathrm{mi}$, zarządzania zasobami ludzkimi oraz zarządzania ryzykiem. Zaczęły także powstawać standardy dedykowane konkretnym branżom, np. motoryzacyjnej, spożywczej oraz medycznej. Także szeroko rozumiana działalność edukacyjno-doradcza znalazła się w spektrum zainteresowań ISO. Powołany został komitet (ISO/PC 288) przygotowujący wymagania dla systemu zarządzania organizacją edukacyjną oraz komitet (ISO/PC 280) opracowujący wytyczne dla firm świadczących usługi konsultingowe z zakresu zarządzania. W ramach ISO funkcjonuje również Komitet Techniczny (ISO/TC 232), który zajmuje się opracowywaniem oraz aktualizacją norm dotyczących usług edukacyjnych świadczonych poza formalnym systemem edukacyjnym, tj. poza szkołami i uczelniami. Komitet ten opracował dwie normy:

- ISO 29990 - zawierającą podstawowe wymagania w zakresie organizowania, realizacji i monitorowania usług edukacyjno-szkoleniowych,

- ISO 29991 - zawierającą wymagania dla szkół językowych.

Ich pojawienie się nie zakończyło działalności ISO w tym zakresie. Prowadzone są prace zmierzające do opracowania kolejnych norm dotyczących usług edukacyjnych świadczonych poza formalnym systemem edukacyjnym (ISO, 2016).

Norma ISO 29990:2010 „Usługi edukacyjne w edukacji nieformalnej i szkoleniach - podstawowe wymagania dla dostawców usług" składa się z czterech rozdziałów. Dwa pierwsze (tj. „Zakres normy” oraz „Terminy i definicje”) mają charakter wprowadzający. Dwa kolejne rozdziały zawierają wymagania, które powinni spełniać dostawcy usług szkoleniowych. Rozdział 3. „Usługi edukacyjne” składa się z pięciu podrozdziałów, a rozdział 4 „Zarządzanie jednostką dostarczającą usługi edukacyjne" podzielony został na dziesięć podrozdziałów. Strukturę tych rozdziałów przedstawiono $\mathrm{w}$ tabeli 1 .

Norma ISO 29990 nie została opublikowana przez Polski Komitet Normalizacyjny, nie istnieje więc polskojęzyczna wersja tego dokumentu. Zapewne z tego powodu certyfikat na zgodność z tą normą uzyskało w Polsce zaledwie kilka organizacji (Batko, Rogala, 2015, s. 4).

Niezależnie od normy ISO 29990 (która jest normą międzynarodową) powstawały i powstają inne standardy dotyczące zarządzania firmami szkoleniowymi lub prowadzenia działalności szkoleniowej. Mają one jednak węższy, zwykle ograniczony do jednego kraju, zasięg. Na przykład w Tajwanie opracowany został Tajwański System Jakości Szkoleń (Chang, Chen, 2013), natomiast w Niemczech wprowadzony został standard AZWV dotyczący uznawania i dopuszczania kursów dokształcających (Heene, Jodkowska, 2014). W Polsce stosowane są Małopolskie Standardy Usług Szkoleniowo-Edukacyjnych - MSUES (Rogala, Wawak, 2015, s. 137-148). Zostały one opracowane przez Wojewódzki Urząd Pracy w Krakowie we współpracy z grupą naukowców z Uniwersytetu Jagiellońskiego. Przesłanką podjęcia prac były sygnały świadczące o tym, że funkcjonowanie części firm szkoleniowych nie spełnia oczekiwań uczestników szkoleń. Pojawiła się więc konieczność weryfikacji ich działalności (Wawak i in., 2017, s. 176-191).

Przyjęty przez Wojewódzki Urząd Pracy w Krakowie model składa się z dwudziestu kryteriów (zwanych standardami), które ujęte zostały w czterech modułach dotyczących:

1) usług edukacyjno-szkoleniowych,

2) kompetencji i rozwoju kadry szkoleniowej,

3) infrastruktury, organizacji i obsługi klienta oraz

4) zarządzania jakością usług szkoleniowych.

$\mathrm{W}$ ramach każdego modułu sformułowanych zostało pięć standardów (tab. 2).

Powołane przez Wojewódzki Urzędzie Pracy w Krakowie Centrum Zapewniania Jakości Kształcenia w Małopolsce przeprowadza audyty oceniające stopień spełnienia tych standardów przez wybrane firmy szkoleniowe (Wojewódzki Urząa Pracy w Krakowie, 2012).

Tabela 1. Struktura wymagań zawartych w normie ISO 29990

\begin{tabular}{|l|l|}
\hline \multicolumn{1}{|c|}{$\begin{array}{c}\text { Rozdział 3. } \\
\text { „Usługi edukacyjne” }\end{array}$} & \multicolumn{1}{c|}{\begin{tabular}{c}
\multicolumn{1}{c|}{ Rozdział 4 } \\
„Zarządzanie jednostką dostarczającą usługi edukacyjne”
\end{tabular}} \\
\hline 3.1. Określanie potrzeb edukacyjnych & 4.1. Wymagania ogólne w zakresie zarządzania \\
3.2. Projektowanie usług edukacyjnych & 4.2. Strategia oraz zarządzanie biznesem \\
3.3. Dostarczanie usług edukacyjnych & 4.3. Przegląd zarządzania \\
3.4. Monitorowanie dostarczania usług edukacyjnych & 4.4. Działania zapobiegawcze oraz działania korygujące \\
3.5. Ocena przeprowadzana przez dostawcę usług edukacyjnych & 4.5. Zarządzanie finansami oraz zarządzanie ryzykiem \\
& 4.6. Zarządzanie zasobami ludzkimi \\
& 4.7. Zarządzanie komunikacją (wewnętrzną/zewnętrzną) \\
& 4.8. Alokacja zasobów \\
& 4.9. Audity wewnętrzne \\
& 4.10. Opinie zwrotne stron zainteresowanych \\
\hline
\end{tabular}


Standardy zarządzania firmami szkoleniowymi różnią się między sobą zasięgiem, strukturą oraz sposobem formułowania wymagań. Cechą, która je łączy, jest to, że każdy $\mathrm{z}$ tych dokumentów zawiera przemyślany i kompleksowy (zdaniem ich twórców) zestaw kryteriów, których spełnienie ma zapewnić organizacji odpowiednio wysoki poziom jakości funkcjonowania.

\section{Metoda badawcza}

$\mathbf{P}$ rzeprowadzone na potrzeby niniejszego artykułu badanie składało się z dwóch etapów. Pierwszym z nich było zidentyfikowanie - na podstawie treści wybranych standardów - czynników mających wpływ na jakość funkcjonowania firm szkoleniowych. Do analizy wybrano normę ISO 29990 oraz Małopolski Standard Usług Edukacyjno-Szkoleniowych. Analiza treści obu dokumentów wykazała, że ich zakres tematyczny jest zbliżony (Rogala, Wawak, 2015, s. 146). Obejmuje on 20 czynników determinujących jakość funkcjonowania firmy szkoleniowej (tab. 3).

Etap drugi badania polegał na ustaleniu znaczenia każdego ze zidentyfikowanych czynników. W tym celu w pierwszym kwartale 2015 roku przeprowadzone zostało badanie ankietowe. Odpowiedni kwestionariusz badawczy wysłano do 147 firm, które z wynikiem pozytywnym przeszły proces oceny prowadzonej przez Centrum Zapewniania Jakości Kształcenia w Małopolsce. Dominowały przedsiębiorstwa posiadające siedzibę na terenie Małopolski, jednak znalazły się wśród nich (około 20\%) także organizacje zlokalizowane $\mathrm{w}$ innych województwach. W piśmie przewodnim poproszono menedżerów o dokonanie oceny z zastosowaniem 5-stopniowej skali pomiaru, gdzie 1 oznaczało nieważny, a 5 oznaczało bardzo ważny. Wypełnione formularze otrzymano z 93 przedsiębiorstw, jednak po wstępnej analizie odrzucono 3 spośród nich, gdyż uznano je za błędnie wypełnione. W próbie znalazły się firmy prowadzące na terytorium Polski szkolenia zawodowe. Większość z nich (69\%) zrealizowała w ciągu $6 \mathrm{~m}$-cy poprzedzających badanie od 6 do 14 szkoleń. Na drugim miejscu znalazły się ex aequo firmy, które w tym samym czasie przeprowadziły od 15 do 34 szkoleń $(10 \%)$ oraz takie, które zrealizowały więcej niż 54 szkolenia (10\%).

W celu oceny rzetelności badań przeprowadzony został test Alfa Cronbacha. Obliczony wskaźnik przyjął wartość 0,884 , co pozwoliło stwierdzić, że rzetelność skali była prawidłowa (skala uznawana jest za prawidłową, gdy wskaźnik przyjmuje wartość wyższą niż 0,7$)$.

\section{Wyniki badań}

7 daniem respondentów, wszystkie 20 czynników objętych badaniem należy uznać za ważne (tab. 3), gdyż każdy z niż uzyskał średnią ocenę wyższą niż 3,5. Średnie oceny znaczenia wymagań przyjęły wartości od 3,54 (Gotowość na sytuacje awaryjne - udokumentowana procedura) do 4,86 (Trenerzy dysponują

Tabela 2. Struktura Małopolskich Standardów Usług Edukacyjno-Szkoleniowych

\begin{tabular}{|c|c|c|c|}
\hline \multicolumn{4}{|c|}{ Standardy dotyczące: } \\
\hline $\begin{array}{c}\text { usługi } \\
\text { edukacyjno-szkoleniowej: }\end{array}$ & $\begin{array}{l}\text { kompetencji } \\
\text { i rozwoju kadry } \\
\text { szkoleniowej: }\end{array}$ & $\begin{array}{l}\text { infrastruktury, organizacji } \\
\text { i obsługi klienta: }\end{array}$ & $\begin{array}{l}\text { zarządzania jakością } \\
\text { usług szkoleniowych: }\end{array}$ \\
\hline $\begin{array}{l}\text { 1. Cel i zakres tematyczny } \\
\text { szkolenia są dostosowane do } \\
\text { potrzeb uczestników. } \\
\text { 2. Programy nauczania } \\
\text { są opisane w języku efektów } \\
\text { uczenia się. } \\
\text { 3. Programy szkoleniowe } \\
\text { są oparte na aktualnej, } \\
\text { rzetelnej wiedzy i realizowane } \\
\text { w adekwatnej do celów } \\
\text { formie. } \\
\text { 4. Instytucja szkoleniowa } \\
\text { prowadzi działania } \\
\text { wspierające utrwalanie } \\
\text { efektów uczenia się. } \\
\text { 5. Instytucja szkoleniowa } \\
\text { systematycznie bada rezultaty } \\
\text { prowadzonych szkoleń. }\end{array}$ & $\begin{array}{l}\text { 6. Instytucja szkoleniowa } \\
\text { dysponuje kadrą } \\
\text { odpowiedzialną za } \\
\text { merytoryczną jakość usług. } \\
\text { 7. Wiedza teoretyczna } \\
\text { i praktyczna kadry } \\
\text { szkoleniowej jest odpowiednia } \\
\text { do zakresu szkoleń oraz ich } \\
\text { celów edukacyjnych. } \\
\text { 8. Kadra szkoleniowa posiada } \\
\text { kompetencje społeczne } \\
\text { i metodyczne związane } \\
\text { z kształceniem osób } \\
\text { dorosłych. } \\
\text { 9. Kadra szkoleniowa aktywnie } \\
\text { uczestniczy w działaniach } \\
\text { rozwojowych i aktualizuje } \\
\text { własne kompetencje. } \\
\text { 10. Kadra szkoleniowa wnosi } \\
\text { wkład w popularyzację wiedzy } \\
\text { i wymianę dobrych praktyk } \\
\text { w zakresie LLL. }\end{array}$ & $\begin{array}{l}\text { 11. Instytucja szkoleniowa } \\
\text { zapewnia uczestnikom } \\
\text { obsługę i sprawną organizację } \\
\text { szkolenia. } \\
\text { 12. Instytucja organizuje } \\
\text { szkolenia w warunkach } \\
\text { zapewniających komfort } \\
\text { uczestnikom i higienę pracy } \\
\text { umysłowej. } \\
\text { 13. Instytucja planuje czas } \\
\text { szkolenia w sposób sprzyjający } \\
\text { komfortowi uczestników } \\
\text { i higienie pracy umysłowej. } \\
\text { 14. Instytucja szkoleniowa } \\
\text { dysponuje różnorodnymi } \\
\text { środkami technicznymi } \\
\text { i materiałami wspierającymi } \\
\text { uczenie. } \\
\text { 15. Instytucja szkoleniowa jest } \\
\text { przygotowana do reagowania } \\
\text { na nieprzewidziane sytuacje } \\
\text { i zastrzeżenia klientów. }\end{array}$ & $\begin{array}{l}\text { 16. Instytucja szkoleniowa } \\
\text { dysponuje spójną koncepcją } \\
\text { funkcjonowania określającą } \\
\text { jej sposób działania i kierunki } \\
\text { rozwoju. } \\
\text { 17. Instytucja szkoleniowa } \\
\text { publikuje rzetelną informację } \\
\text { o oferowanych usługach. } \\
\text { 18. Instytucja szkoleniowa } \\
\text { stosuje systemowe rozwiązania } \\
\text { wspierające wysoką jakość } \\
\text { świadczonych usług. } \\
\text { 19. Instytucja szkoleniowa } \\
\text { upowszechnia wiedzę } \\
\text { o dobrych praktykach } \\
\text { w zapewnianiu jakości } \\
\text { szkoleń. } \\
\text { 20. Instytucja szkoleniowa } \\
\text { oferuje usługi w zgodzie } \\
\text { z obowiązującymi normami } \\
\text { prawnymi i wymogami } \\
\text { narzucanymi przez } \\
\text { zewnętrzne regulacje. }\end{array}$ \\
\hline
\end{tabular}


Tabela 3. Czynniki wpływające na sukces firmy szkoleniowej

\begin{tabular}{|c|c|}
\hline $\mathrm{Nr}$ & Wyszczególnienie \\
\hline 1 & $\begin{array}{l}\text { Posiadanie w ofercie unikatowych } \\
\text { tematów szkoleń }\end{array}$ \\
\hline 2 & $\begin{array}{l}\text { Posiadanie w ofercie szkoleń najpopularniejszych w danym } \\
\text { okresie na rynku }\end{array}$ \\
\hline 3 & Szeroki zestaw tematów proponowanych szkoleń \\
\hline 4 & $\begin{array}{l}\text { Precyzyjne zdefiniowanie oczekiwań uczestników każdego } \\
\text { szkolenia (przed szkoleniem) }\end{array}$ \\
\hline 5 & $\begin{array}{l}\text { Zapewnienie uczestnikom szkoleń odpowiednich materiałów } \\
\text { szkoleniowych }\end{array}$ \\
\hline 6 & $\begin{array}{l}\text { Zapewnienie uczestnikom szkoleń dodatkowego wsparcia } \\
\text { po zakończeniu szkoleń }\end{array}$ \\
\hline 7 & $\begin{array}{l}\text { Trenerzy dysponują odpowiednią wiedzą z zakresu } \\
\text { prowadzonych szkoleń }\end{array}$ \\
\hline 8 & $\begin{array}{l}\text { Trenerzy dysponują odpowiednią praktyką zawodową } \\
\text { z zakresu prowadzonych szkoleń }\end{array}$ \\
\hline 9 & Trenerzy potrafią prowadzić szkolenia w sposób interesujący \\
\hline 10 & Sprawna obsługa administracyjna szkoleń \\
\hline 11 & $\begin{array}{l}\text { Udokumentowane procedury dotyczące szkoleń } \\
\text { (przygotowania, przeprowadzania, oceny jakości itp.) }\end{array}$ \\
\hline 12 & $\begin{array}{l}\text { Odpowiednie harmonogramy szkoleń (liczba godzin, } \\
\text { odpowiednio zaplanowane przerwy itp.) }\end{array}$ \\
\hline 13 & $\begin{array}{l}\text { Sprawna komunikacja na linii: osoba odpowiedzialna za } \\
\text { organizację szkolenia - trenerzy }\end{array}$ \\
\hline 14 & $\begin{array}{l}\text { Odpowiednie sale (dostosowane do specyfiki szkoleń } \\
\text { i uczestników) }\end{array}$ \\
\hline 15 & Odpowiednie wyposażenie sal (projektor, tablica itp.) \\
\hline 16 & $\begin{array}{l}\text { Odpowiednie sposoby kontrolowania jakości szkoleń (badanie } \\
\text { satysfakcji klientów, hospitacje itp.) }\end{array}$ \\
\hline 17 & Gotowość na sytuacje awaryjne (udokumentowana procedura) \\
\hline 18 & $\begin{array}{l}\text { Cykliczne podejmowanie działań doskonalących w zakresie } \\
\text { sposobów prowadzenia szkoleń }\end{array}$ \\
\hline 19 & Sformułowanie wizji i misji organizacji \\
\hline 20 & $\begin{array}{l}\text { Wysoka aktywność informacyjno-promocyjna (www, broszury } \\
\text { itd.) }\end{array}$ \\
\hline
\end{tabular}

Źródło: (Rogala, Wawak, 2015, s. 146) odpowiednią wiedzą z zakresu prowadzonych szkoleń). $\mathrm{Na}$ rysunku 1 zaprezentowano rozkład średnich ocen przyznanych poszczególnym czynnikom.

Analizując wyniki przeprowadzonych badań, stwierdzić można, że kluczowym warunkiem zapewnienia wysokiej jakości funkcjonowania jest zaangażowanie odpowiednich trenerów, gdyż aż trzy wymagania uznane za najważniejsze dotyczą bezpośrednio kadry szkoleniowej. Zostały one sformułowane w następujący sposób:

- trenerzy dysponują odpowiednią wiedzą z zakresu prowadzonych szkoleń (średnia ocena: 4,86 ),

- trenerzy potrafią prowadzić szkolenia w sposób interesujący (średnia ocena: 4,79) oraz

- trenerzy dysponują odpowiednią praktyką zawodową z zakresu prowadzonych szkoleń (średnia ocena: $4,78)$.

Należy podkreślić to, że oceny wystawione tym zagadnieniom przez poszczególnych menedżerów były relatywnie silnie zróżnicowane. Podczas gdy odchylenie standardowe ocen dla wszystkich zagadnień wyniosło 1,06 , to dla tych trzech kryteriów przyjęło ono następujące wartości: 1,13 (trenerzy dysponujący odpowiednią wiedzą z zakresu prowadzonych szkoleń); 1,15 (trenerzy dysponujący odpowiednią praktyką zawodową z zakresu prowadzonych szkoleń) oraz 1,2 (trenerzy potrafiący prowadzić szkolenia w sposób interesujący). Dodatkowo okazało się, że pomiędzy ocenami wystawianymi tym trzem wymaganiom występuje wyraźna pozytywna zależność (do jej zbadania wykorzystano korelację liniową Pearsona). Przedstawione powyżej informacje upoważniają do stwierdzenia, że jakość kadry szkoleniowej jest wprawdzie najważniejszym czynnikiem decydującym o jakości funkcjonowania firmy szkoleniowej, istnieją jednak firmy, w których znaczenie tego czynnika jest nieco niższe, oraz takie, w których jest ono nieco wyższe. Można przypuszczać, że kryterium różnicującym w tym zakresie jest tematyka prowadzonych szkoleń.

Warto zwrócić uwagę na to, że konieczność zapewnienia odpowiedniej kadry szkoleniowej podkreślana jest $\mathrm{w}$ obu $\mathrm{z}$ uwzględnionych $\mathrm{w}$ badaniu standardów. W normie ISO 29990 poświęcony został temu tematowi podrozdział 4.6. „Zarządzanie zasobami ludzkimi” (zob.

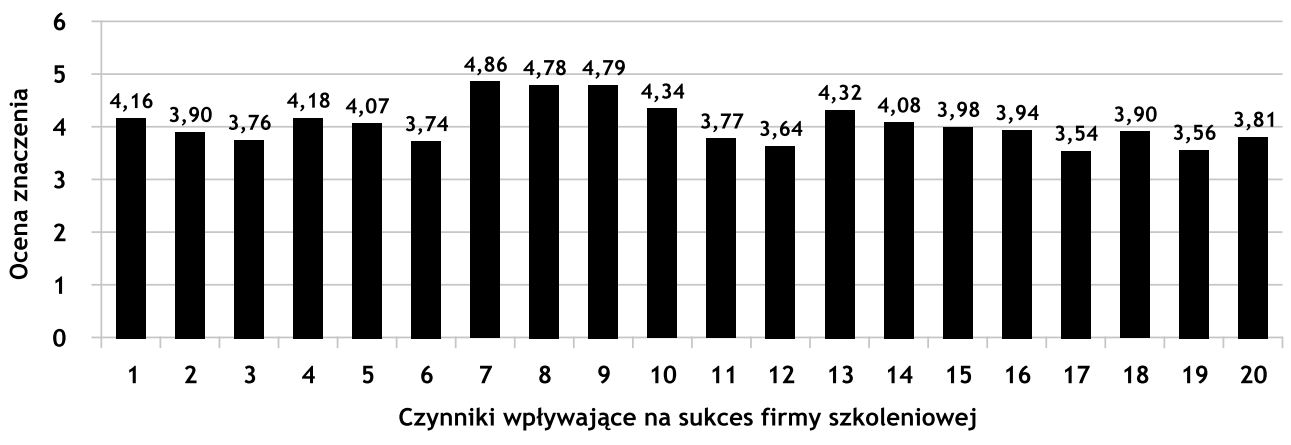

Rys. 1. Średnia ocena znaczenia poszczególnych czynników wg tabeli 3

Źródto: opracowanie wtasne 
tabela 1), który składa się z dwóch części. W pierwszej $\mathrm{z}$ nich zwrócono uwagę na potrzebę zapewnienia odpowiednich kompetencji pracowników, przy czym wyodrębniono trzy grupy tych kompetencji, tj.

- związane z dostarczaniem usług edukacyjnych, np. identyfikowanie potrzeb $\mathrm{w}$ zakresie nauczania, stosowanie teorii nauczania, bycie ekspertem $\mathrm{w}$ danej dziedzinie,

- osobowe, np. zarządzanie konfliktem i motywowanie osób oraz

- biznesowe, np. nawiązywanie kontaktu ze stronami zainteresowanymi, zarządzanie wynikami biznesowymi i formułowanie polityki szkoleniowej (Kłosowski, 2014, s. 22-23).

W drugiej części omawianego podrozdziału wskazano działania pozwalające zapewnić odpowiedni poziom kompetencji personelu. Znalazły się wśród nich m.in. ocena kompetencji pracowników z uwzględnieniem specyfiki wykonywanych przez nich zadań, badanie motywacji oraz zadowolenia personelu, a także ciągłe doskonalenie kompetencji i ocena skuteczności podejmowanych w tym zakresie działań (ISO 29990, 2010, s. 8). Z kolei w MSUES kadra szkoleniowa uznana została za jeden $\mathrm{z}$ czterech obszarów objętych standardami (pozostałe obszary to: (1) usługa szkoleniowa; (2) infrastruktura, organizacja i obsługi klienta oraz (3) zarządzanie). Zagadnienia związane $\mathrm{z}$ trenerami uwzględnione zostały w pięciu kolejnych standardach - od 6 do 10 (zob. tabela 2).

Na drugim miejscu znalazły się zagadnienia związane z obsługą administracyjną szkoleń. Grupa ta obejmuje następujące czynniki: (1) sprawna obsługa administracyjna szkoleń, (2) sprawna komunikacja na linii: osoba odpowiedzialna za organizację szkolenia - trenerzy oraz (3) zapewnienie uczestnikom szkoleń odpowiednich materiałów szkoleniowych. Należy zauważyć, że dwa pierwsze czynniki uzyskały wyraźnie wyższe oceny (odpowiednio: 4,34 oraz 4,32) niż czynnik trzeci $(4,07)$. $\mathrm{W}$ ramach tych czynników znajdują się takie działania, jak np.: zebranie danych o uczestnikach i przekazanie ich trenerowi, wysłanie uczestnikom przypomnienia o miejscu i godzinie rozpoczęcia szkolenia, wydrukowanie listy obecności, wydrukowanie i oprawa materiałów szkoleniowych, rozdanie, a następnie zebranie ankiet ewaluacyjnych, a także rozesłanie materiałów uczestnikom szkolenia.

Trzecia grupa związana jest $\mathrm{z}$ ofertą szkoleniową. Obejmuje ona dwa czynniki:. (1) precyzyjne zdefiniowanie oczekiwań uczestników każdego szkolenia (średnia ocena: 4,18) oraz (2) posiadanie w ofercie unikatowych tematów szkoleń (średnia ocena: 4,16). W ramach tej grupy czynników wymaga się m.in. wykorzystywania ogólnodostępnych informacji o potrzebach występujących na rynku pracy (opublikowanych raportów, stron internetowych itd.), a także prowadzenia własnych badań, w tym diagnozowanie potrzeb organizacji zamawiającej szkolenie lub pracowników zgłaszających się na szkolenie. Warto zauważyć, że menedżerowie firm szkoleniowych za ważniejsze uznali posiadanie unikatowych szkoleń niż posiadanie najpopularniejszych w danym okresie szkoleń.

Respondenci uznali także, że istotne jest zapewnienie odpowiednich sal szkoleniowych. Czynnik ten uzyskał średnią ocenę na poziomie 3,9 . W jego ramach uwzględnione powinny być zagadnienia dotyczące m.in. odpowiedniej wielkości sali szkoleniowej, dostępu do światła dziennego, układu sali dostosowanego do specyfiki szkolenia oraz możliwości wykorzystania dodatkowej sali do pracy w grupach lub zorganizowania posiłku.

Jako zaskakujący uznać można fakt, że sformułowanie wizji i misji ocenione zostało za jeden z najmniej istotnych czynników. Znalazł się on na przedostatniej pozycji ze średnią oceną wynoszącą 3,556. Ponadto okazało się, że oceny przyznawane temu kryterium są silnie skorelowane $\mathrm{z}$ dwoma innymi wymaganiami:

a) $\mathrm{z}$ cyklicznym podejmowaniem działań doskonalących w zakresie sposobów prowadzenia szkoleń,

b) $\mathrm{z}$ gotowością na sytuacje awaryjne (ten czynnik uznany został za najmniej istotny).

Wszystkie te kryteria zostały relatywnie nisko ocenione przez menedżerów. Uwagę zwraca fakt, iż czynniki te nie są wprost powiązane $z$ bieżącą i operacyjną działalnością, lecz odnoszą się do zarządzania strategicznego. Można więc sformułować wniosek, że menedżerowie badanych firm szkoleniowych koncentrują się na działaniach operacyjnych oraz na zasobach, mniejszą wagę przywiązując do zarządzania strategicznego.

\section{Podsumowanie}

W artykule zidentyfikowane zostały czynniki determinujące jakość funkcjonowania firm szkoleniowych. W celu wstępnego ich określenia wykorzystane zostały wybrane standardy dotyczące zarządzania organizacjami świadczącymi usługi szkoleniowe. Dokumenty tego typu zawierają zestawy wymagań, które powinny być spełniane przez firmy szkoleniowe dążące do zapewnienia odpowiedniej jakości świadczonych usług. Mogą one być wykorzystywane w procesach oceny organizacji (np. jako podstawa certyfikacji). $\mathrm{Na}$ podstawie analizy treści tych standardów określono listę 20 czynników, których znaczenie zostało następnie ocenione przez menedżerów 90 firm szkoleniowych. Za najważniejsze determinanty jakości funkcjonowania firm szkoleniowych uznano odpowiednią kadrę szkolącą, a także obsługę administracyjną szkoleń. Relatywnie niską rangę przyznano natomiast zagadnieniom związanym z zarządzaniem strategicznym.

Należy podkreślić, że przedstawiony w niniejszym artykule zestaw czynników wpływających na sukces firmy szkoleniowej nie stanowi zamkniętego katalogu. Można przypuszczać, że istnieją jeszcze inne ważne czynniki, ale nie zostały zidentyfikowane, ponieważ nie są one uwzględnione w żadnym ze standardów wykorzystanych $\mathrm{w}$ przeprowadzonym badaniu. Ponadto można zakładać, że realne znaczenie poszczególnych czynników może być uzależnione od specyfiki firmy 
szkoleniowej (np. od jej wielkości lub tematyki prowadzonych szkoleń). Jednak tego typu analizy nie były tematem powyższego opracowania i wymagają przeprowadzenia dodatkowych, znacznie rozszerzonych, badań empirycznych.

Wnioski wynikające $\mathrm{z}$ przeprowadzonej analizy powinny być uwzględniane zarówno na etapie projektowania/rozpoczynania działalności szkoleniowej, jak i na etapie oceniania oraz doskonalenia istniejącej już firmy. Wypracowanie najlepszych możliwych rozwiązań w ramach każdego z tych czynników uznać należy za kluczowe wyzwanie dla osób zarządzających firmami szkoleniowymi.

\section{dr Piotr Rogala \\ Uniwersytet Ekonomiczny we Wrocławiu Wydziat Ekonomii, Zarządzania i Turystyki e-mail: piotr.rogala@ue.wroc.pl}

\section{Bibliografia}

[1] Baraki A.H., van Kemenade E. (2013), Effectiveness of Technical and Vocational Education and Training (TVET), „The TQM Journal”, Vol. 25, No. 5, pp. 492-506.

[2] Batko R., Rogala P. (2015), Standardy jakości w działalności edukacyjno-szkoleniowej, „Problemy Jakości”, Nr 1, s. $2-5$.

[3] Chang W.L., Chen S.T. (2013), The Performance of Taiwan's Training Quality Excellence System, „Total Quality Management", Vol. 24, No. 5, pp. 561-576.

[4] Davies E. (2007), The Training Manager's Desktop Guide, Thorogood Publishing, London.

[5] Gableta M. (2005), Potencjał ludzki, [w:] J. Lichtarski (red.), Podstawy nauki o przedsiębiorstwie, Wyd. AE we Wrocławiu, Wrocław, s. 212-220.

[6] Guerrazzi M. (2016), The Effect of Training on Italian Firms' Productivity: Microeconomic and Macroeconomic Perspectives, „International Journal of Training and Development", Vol. 20, No. 1, pp. 38-57.

[7] Henne J., Jodkowska L. (2014), New ISO 29990:2010 as Value Added to Non-Formal Education Organizations in the Future, [in:] T. Marek, W. Karwowski, M. Frankowicz, J. Kantola, P. Zgaga (red.), Human Factors of a Global Society, CRC Press, Boca Raton, London, New York, pp. 905-915.

[8] ISO 29990 Learning Services for Non-formal Education and Training - Basic Requirements for Service Providers (2010), International Organization for Standardization, Geneva.

[9] ISO, Technical Committees, https://www.iso.org/technical-committees.html, access date: 10.10.2016.

[10] Kłosowski D. (2014), System zarządzania usługami edukacyjnymi wg ISO 29990:2010, Wydawnictwo Wiedza i Praktyka sp. z o.o., Warszawa.

[11] Lee G.J. (2012), Firm Size and the Effectiveness of Training for Customer Service, „The International Journal of Human Resource Management", Vol. 23, No. 12, pp. 2597-2613.
[12] Mika A. (2010), Rynek ustug szkoleniowych $w$ Polsce, Studia i Prace Kolegium Zarządzania i Finansów, Nr 102, s. 119-130.

[13] Nasseef M.A. (2014), Measuring the Quality of Educational Service Provided by Business Administration Department Using the SERVQUAL Instrument at King Abdul-Aziz university - Jeddah, „Journal of Business Studies Quarterly", Vol. 5, No. 4, pp. 147-172.

[14] PKO Bank Polski, Monitor Branżowy, 2016, http:// www.pkobp.pl/media_files/6df66082-489e-441f-9413-f66a726c945b.pdf, data dostępu: 11.10.2016 r.

[15] PN-EN ISO 9000 (2015), Systemy zarządzania jakością. Podstawy i terminologia, Polski Komitet Normalizacyjny, Warszawa.

[16] Rogala P., Wawak S. (2015), Dedicated Standards for Quality Management in Training Companies, „Nauki o Zarządzaniu”, Vol. 24, No. 3, pp. 137-148.

[17] Suchodolski A. (2010), Rozwój potencjału społecznego firmy, [w:] T. Listwan (red.), Zarzadzanie kadrami, C.H. Beck, Warszawa, s. 211-234.

[18] Świeży M. (red.), (2012), Przewodnik po Małopolskich Standardach Usług Edukacyjno-Szkoleniowych, Wojewódzki Urząd Pracy w Krakowie, Kraków.

[19] Wawak S., Batko R., Rogala P. (2017), Quality Management Standard for Learning Service Providers - Critical Analysis, „Problemy Zarządzania”, Vol. 15, No. 1, pp. 176-191.

[20] Wawer M. (2012), Rozwój rynku usług szkoleniowych w Polsce - teraźniejszość i przyszłość, Zeszyty Naukowe Uniwersytetu Szczecińskiego, Nr 96, s. 443-454.

[21] Wojewódzki Urząd Pracy w Krakowie, 2012, Małopolskie Standardy Usług Edukacyjno-szkoleniowych, http:// bonyefs.pl/malopolskie-standardy-uslug-edukacyjno-szkoleniowych-msues, data dostępu: 11.10.2016 r.

[22] Zimniewicz K. (2003), Wspótczesne koncepcje i metody zarzązania, PWE, Warszawa.

\section{Determinants Influencing Quality of Training Companies Functioning}

\section{Summary}

The paper defines a set of twenty factors determining the success of companies that offer training services. The considerations have been based on the content analysis of selected standards for training service providers, (i.e. ISO 29990 and MSUES) and on the results of the survey, which included 90 managers of Polish training companies. As a result, it has been concluded that the key challenge for the managers of a training company is to provide appropriate trainers since 3 factors identified by the respondents as the most important concern the training staff. These factors are: (1) coaches with extensive knowledge in the field of training, (2) coaches with appropriate professional practice in the field of training and (3) coaches capable of providing training in an interesting way.

\section{Keywords}

training company, ISO 29990, MSUES 